Samuel Fernández

Profesor de la Facultad de Teología

Pontificia Universidad Católica de Chile

\title{
El Discurso verídico de Celso contra los cristianos. Críticas de un pagano del siglo II a la credibilidad del cristianismo
}

\section{INTRODUCCIÓN: CELSO Y SU DISCURSO VERÍDICO (1)}

Celso escribió su obra anticristiana, titulada el Discurso verídico, probablemente entre el año 176 y 180. El Discurso verídico no nos ha llegado completo por tradición directa, pero es posible hacerse una idea muy precisa del texto y de su contenido, por medio de los múltiples y a veces amplios fragmentos citados textualmente por Orígenes, en su minuciosa réplica llamada Contra Celso (2). Incluso algunos han intentado, con resultados satisfactorios, una reconstrucción del texto del Discurso de Celso (3).

(1) Para una presentación del status quaestionis de la investigación sobre el Contra Celso, cf. A. Le Boulluec, Vingt ans de recherches sur le Contre Celse: État des lieux, en L. Perrone (Ed.), Discorsi di verità. Paganesimo, giudaismo e cristianesimo a confronto nel Contro Celso di Origene, SEA 61, Roma 1998, pp. 9-28. Utilizamos con notables modificaciones la traducción de D. Ruiz Bueno, Orígenes Contra Celso, BAC, Madrid 1967.

(2) A Celso solo lo conocemos por medio de Orígenes, cf. M. Fédou, Christianisme et religions païennes dans le Contre Celse d'Origène (Théologie Historique 81), Paris 1988, p. 41. Para la fecha del Discurso verídico, cf. Origène, Contra Celse, Introduction générale tables et index par M. Borret, Paris 1976, (SCh 227) V, p. 129. El Contra Celso fue escrito por Orígenes por el año 249, es decir, al final de su vida, cf. P. Nautin, Origène, Sa vie et son oevre, Paris 1977, p. 381. En cuanto a la difusión de la obra de Celso, cf. J. Schwartz, Du testament de Lévi au Discours véritable de Celse, RHPhR 40 (1960) pp. 125-145; Idem, L'épître à Diognète, RHPhR 48 (1968) pp. 46-53; Idem, Celsus redivivus, RHPhR 53 (1973) pp. 399-405; J.M. Vermander, De quelques répliques à Celse dans le Proteptique de Clément d'Alexandrie, RÉAug 23 (1977) pp. 3-17; Idem, Théophile d'Antioche contre Celse: Ad Autolycum III, RÉAug 17 (1971) pp. 203-225; Idem, Celse, source et adversaire de Minucio Felix, RÉAug 17 (1971) pp. 13-25; Idem, De quelques répliques à Celse dans l'Apologeticum de Tertullien, RÉAug 16 (1970) pp. 205-225; M. Borret, Origène. Contre Celse V (SCh, 227), Paris 1976, pp. 192-198.

(3) Los intentos de reconstrucción textual del Discurso verídico están indicados en R.J. Hoffmann, Celsus On the True Doctrine. A Discourse Against the Christians, Oxford University Press, 1987, pp. 44-45. 
Si bien Celso frecuentemente ridiculiza las doctrinas cristianas, hay que reconocer que sus objeciones, aun siendo ofensivas, no son simples insultos, y que, por lo general, no se vale de los chismes populares tan comunes en esa época (4).

\section{¿Qué tipo de cristianismo es el atacado por Celso?}

Por lo general se considera que Celso tenía un conocimiento aceptable del cristianismo. Su conocimiento de la Escritura, sin ser profundo, es bueno (5). Pero, para comprender la fisonomía de los destinatarios de las críticas de Celso, es necesario hacer un par de precisiones.

Al lector moderno le puede parecer que Celso "mezcla" elementos cristianos ortodoxos con ideas heréticas, o que confunde la doctrina de "la Gran Iglesia" con la enseñanza de algunas sectas cristianas. Por ejemplo, atribuye a los cristianos ideas marcionitas y gnósticas. Pero esto no se debe tanto a una mala intención de Celso, como al hecho de que por el año 170 ni siquiera un cristiano corriente era capaz de establecer límites claros entre ortodoxia y herejía. Es ilustrativo que Ire-

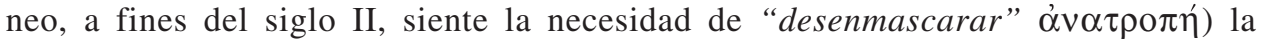
herejía para refutarla (tal como lo indica el título de su principal obra). No podemos, entonces, culpar a Celso de "mezclar" o "confundir" lo que, en realidad, aún no estaba bien diferenciado (6).

También se puede pensar que Celso deforma el cristianismo para atacarlo con mayor facilidad. El Discurso verídico refleja un cristianismo muy vulgar, que no coincide con lo que nos transmiten las fuentes cristianas escritas. Ante esto, es necesario recordar que el costo de escribir y copiar una obra en la antigüedad favoreció la transmisión solo de los textos de mayor valor, quedando los demás en el olvido. Y así, en términos generales, podemos suponer que los textos cristianos que conservamos, son testimonio del cristianismo intelectualmente más elaborado, quedando indocumentadas las expresiones cristianas más vulgares (de ahí que nuestro conocimiento de la antigüedad es por definición sesgada). Las críticas de Celso van contra los cristianos que él ha conocido: posiblemente predicadores ambulantes casi sin preparación. Un detalle de los Hechos nos ilustra algo de esta situación: "Apolo comenzó a hablar con valentía en la sinagoga. Al oírle Aquila y Priscila, le tomaron consigo y le

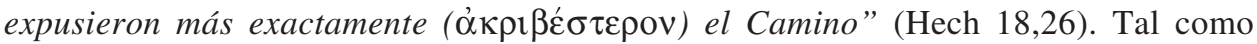
Apolo que, con mucha valentía pero poquísima preparación, se largó a predicar, podemos imaginar una proliferación de predicadores que proclamaban por doquier un cristianismo muy poco reflexionado, con todo el riesgo que ello implicaba. Por lo anterior, es razonable pensar que Celso sesgadamente seleccionara de entre las expresiones cristianas las más vulgares y frágiles para dar mayor brillo a su ataque; pero ello no nos autoriza a pensar que necesariamente el Discurso verídico da una imagen

(4) Las calumnias más repetidas son las de ateísmo, antropofagia, y practicar ritos inmorales. Y están bien documentadas por los apologistas griegos, Minucio Felix y Tertuliano.

(5) Cf. S. Benko, Pagan Criticism of Christianity During the First Two Centuries A.D., en H. Temporini-W. Haase, Eds. (ANRW, II 23/2), Berlin-New York 1980, pp. 1055-1118; M. Simonetti, La Sacra Scrittura nel Contro Celso, en Discorsi di verità (cit.), pp. 97-114.

(6) Cf. M. Simonetti, Ortodossia ed Eresia tra I e II Secolo, Soveria Mannelli 1994. 
falsa del cristianismo de la segunda mitad del siglo segundo; da una imagen parcial e incompleta, pero no falsa. Ahora, a la pregunta ¿qué representatividad tenía este tipo de cristianismo? Es muy difícil, sino imposible, dar una respuesta.

El presente artículo intenta reconstruir y sistematizar las críticas de Celso a la credibilidad del cristianismo. No tiene el propósito de resolverlas, por eso no se hace mención a las correspondientes respuestas de Orígenes (que, por lo demás, están redactadas unos 70 años más tarde, cuando la situación eclesial había cambiado notablemente). No se trata de repetir los insultos, sino de buscar cuál es el núcleo de la crítica de Celso. Y si se repiten algunos insultos es porque ellos contienen una crítica más profunda.

\section{NO HAY MOTIVOS PARA CREER}

\section{Reacción contra la apologética cristiana}

A partir de los fragmentos del Discurso verídico, es posible reconstruir los argumentos utilizados por los cristianos del siglo segundo para defender su doctrina (7). Los argumentos de la apologética cristiana debieron ser los siguientes:

a) Jesús es el Mesías esperado, pues en él se cumplen las profecías

b) Jesús es Hijo de Dios, pues nació de una Madre Virgen

c) Jesús es el Hijo de Dios, pues realizó milagros

d) La resurrección muestra el carácter divino de Jesús

e) El martirio es prueba de la verdad del cristianismo

a) El argumento de las profecías

Ya en el kerygma primitivo encontramos el uso apologético de las profecías. Los discursos kerygmáticos insisten en que en Jesús de Nazaret "Dios dio cumplimiento a lo que había anunciado por boca de todos los profetas" (Hech 3,18, et passim). El argumento debió ser relevante frente a las comunidades judías, pero repetido mecánica e indiscriminadamente ante los paganos, debió sonar bastante débil. Celso irónicamente critica la solidez del argumento de las profecías:

"Los [cristianos], que admiten el mismo Dios que los judios, nos dirán la sabia sentencia de que 'así tenía que suceder'. ¿Prueba? Porque desde antiguo estaba predicho" (VII,2).

Celso considera que este argumento no es más que un refugio. Puesto que incluso los mismos judíos, que esperaban al Mesías profetizado, no creyeron en

(7) Aquí se debe "jugar a dos bandas": en base a la obra de Orígenes, se reconstruye la de Celso, y en base a las ideas de Celso, se reconstruye la apologética cristiana. 
Jesús (cf. II,8). Por otra parte, con agudeza objeta que: "las profecías se pueden ajustar a miles de otros con mayor verosimilitud que a Jesús” (II,28). Luego, pregunta Celso: ¿por qué Jesús y no otro de los miles en que se pueden aplicar las profecías? (cf. I,50; I,57). El argumento de las profecías, según él, vale solo para los que están siempre dispuestos a ser engañados (cf. II,8).

Respecto de las profecías que Jesús hizo sobre su propia muerte, consignadas en los evangelios, el Discurso verídico simplemente afirma que son inventos de los discípulos para excusar a su Maestro, pues al presentar muerto al Dios inmortal (cosa absurda para Celso), lo justifican diciendo "Él lo predijo todo" (cf. II,15-16). Se queja además de la inconsecuencia de los cristianos que valoran las profecías pronunciadas en Judea y no dan crédito a los oráculos de los griegos (cf. VII,3). En un texto, que traducimos con cierta libertad, Celso establece un interesante principio:

¿Acaso porque los profetas predijeron que el Gran Dios debía ser esclavo, sufrir y morir, tenía Dios que ser esclavo, sufrir y morir, solo porque estaba predicho; para que una vez muerto se creyera $(\pi \iota \sigma \tau \varepsilon v \theta \eta)$ que era Dios? Pero los profetas no pueden predecir eso, puesto que es malo e impío. Luego, no

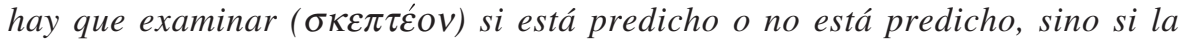

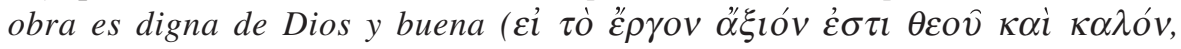
VII, 14).

Celso prioriza la razón por sobre el dato revelado. Algunos de sus contemporáneos cristianos se contentan con el dato bíblico, tal y como lo leen (8). Luego, la central pregunta ¿Cómo es Dios?, se responde desde dos horizontes diferentes:

a. Celso responde: Dios es tal como debe ser, según la razón.

b. Los cristianos, según Celso, responden: Dios es tal como se revela, según la Biblia.

Ambas posturas son parciales e insuficientes, y se plantea así el tema de la compleja relación entre revelación positiva y razón natural; o la, a veces mal planteada, tensión entre el Dios de los filósofos y el Dios de la revelación.

\section{b) El argumento del nacimiento virginal}

A partir de los fragmentos del Discurso verídico se puede deducir que los primeros cristianos aducían el nacimiento virginal de Jesús como una prueba de su divinidad. La insistencia con que Celso transmite calumnias en torno al nacimiento de Jesús muestra la fuerza del argumento; y el hecho que estas calumnias sean de origen judío -Celso las pone en boca de un judío- muestra la antigüedad del mismo argumento (cf. I,28; I,32; I,39; I,69; II,13). En este caso no hay un verdadero cuestionamiento a la predicación cristiana, por parte de Celso, sino simplemente la repetición de una calumnia que busca desacreditar a Jesús.

(8) Más abajo se abordará el problema de las dificultades de una lectura literalista de la Escritura. 


\section{c) El argumento de los milagros}

Otra justificación para probar el carácter divino de Jesús y del cristianismo debió ser el argumento basado en los milagros. Celso dice que los cristianos han

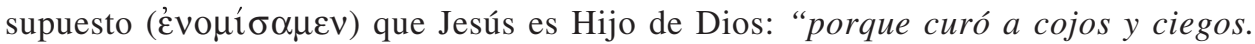
$Y$, de acuerdo a lo que dicen, resucitó algunos muertos” (II,48). Frente a los milagros de Jesús, Celso tiene una actitud ambigua: por una parte tiende a negarlos, cuando dice que Jesús no hizo nada admirable cuando le pidieron que hiciera un signo en el templo (cf. I,67; Jn 10,24), pero por otra parte tiende a darles crédito, cuando afirma que Jesús aprendió magia en Egipto (cf. I,28), y concede que sean verdaderos al menos una pequeña parte de los milagros narrados por los evangelios (9). Pero cuando concede que Jesús ha realizado milagros, "inmediatamente los

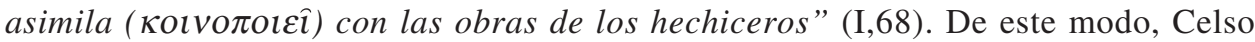
le otorga crédito a los prodigios proclamados por los cristianos, solo para probar que Jesús no es Hijo de Dios sino un hechicero.

Los fragmentos del Discurso verídico indican también el uso apologético de los milagros realizados por los cristianos del siglo II. Celso no duda de la veracidad de estos milagros, pero se los atribuye al poder de los demonios y a la magia (cf. I,6; VI,39-40). Además, con mucha agudeza, denuncia la inconsistencia del argumento de los milagros, en base a las palabras del mismo Jesús (Mt 24-27; 7,22-23), que llaman a no creer en los que hagan milagros:

“;Oh luz de la verdad! Con su propia voz, según lo testifican vuestros escritos, [Jesús] anuncia que vendrán a vosotros otros que se valdrán de milagros semejantes, siendo en realidad hechiceros malvados" $(I I, 49)$.

Por último, dice el pagano, no es necesario tener por Hijo de Dios a los que se supone que han hecho milagros: se cuentan muchos prodigios, como los de Asclepio, Aristeas, Abaris, Hermótimo, Cleomedes y tantos otros griegos (cf. III,3; III,26; III,3134), y en ellos, afirma Celso, "nosotros no hemos creído ('̇ $\iota \iota \sigma \tau \varepsilon v \sigma \alpha \mu \varepsilon v)$ " (I,67).

En definitiva, en un ambiente que ofrece tantos autores de prodigios, el argumento de los milagros no parece sólido a los ojos de Celso, y entonces, ¿qué nos puede inclinar a creer en Jesús?

\section{d) El argumento de la resurrección}

La resurrección debió también ser un argumento cristiano para probar el carácter divino de Jesús. Celso en su discurso hace hablar a un judío que declara: "¿Qué es lo que ha conducido [a los cristianos] sino que predijo que resucitaría después de muerto?" (II,54). El argumento descansa no solo en el hecho de la resurrección, sino también en el hecho de que la resurrección estaba predicha (cf. Mc 8,31;9,31;10,33).

(9) Cf. H. Remus, Pagan-Christian Conflict over Miracle in the Second Century, Cambrige 1983, pp. 104-105; F. Mosetto, I miracoli evangelici nel dibattito tra Celso e Origene, Roma 1986, pp. 25-74. 
Tampoco este argumento impresiona a Celso. En primer lugar, duda de la realidad de la resurrección. Un amplio fragmento concentra las críticas a la veracidad de la resurrección:

"Pero lo que se debe examinar es si alguno, verdaderamente muerto, ha resucitado con su propio cuerpo. ¿O piensan que lo de los demás es un mito (y así parece), pero que ustedes han encontrado un desenlace más noble y verosímil al drama: aquel grito que lanzó desde el madero en el momento de expirar, el terremoto y las tinieblas? ¡Estando vivo no pudo socorrerse a sí mismo, pero después de muerto resucita y muestra las señales de su suplicio, cómo habían sido taladradas las manos! ¿Y quién vio todo esto? Una mujer exaltada, como ustedes dicen, y algún otro del mismo grupo de hechiceros. Ya sea que lo soñara por alguna disposición especial de su espíritu, o bien, se lo imaginara con mente extraviada según su propio deseo, cosa, por cierto, que ha sucedido a muchos otros, o, en fin, lo que es más probable, quisiera impresionar a otros con este prodigio y, con tal engaño, dar ocasión a otros charlatanes" (II,55).

El párrafo es despectivo, pero tras los insultos se leen algunas objeciones serias. Celso comienza por recordar que de muchos se declara que han resucitado: ¿por qué creer en Jesús y no en los demás que supuestamente han resucitado? La impotencia de Jesús en la cruz hace dudar que haya podido resucitar después de muerto: "Para demostrar su divinidad, [Jesús] debiera, por lo menos, haber desaparecido súbitamente del madero” (II, 68). Si vivo era impotente, ¡cuánto más muerto! Más arriba hemos citado el texto en que Celso dice que lo que se debe examinar es si la acción es digna de Dios (cf. VII,14). E indudablemente, Celso considera que morir en la cruz es indigno de Dios; Jesús -según él- debió desaparecer súbitamente de la cruz y evitar una muerte indigna de Dios. Pero, nos preguntamos: ¿Quién establece lo que es digno de Dios?

Y, además, continúa Celso, ¿quiénes son los testigos de la resurrección? Una mujer histérica y un pescador de Galilea. E insiste en la fragilidad de los testimonios de la resurrección:

“Cuando [Jesús] podía presentar una prueba de fe ( $\pi i \sigma \tau \iota \varsigma)$ tan fuerte como su resurrección de entre los muertos, se dejó ver a escondidas y de pasada solo por una mujerzuela y por sus propios cofrades [...] Ajusticiado fue visto por todos, pero resucitado solo por unos pocos” $(I I, 70)$.

Celso objeta también el hecho que Jesús se apareció de modo tan poco claro: "como una sombra" (III,22). ¿Por qué no se apareció resucitado a todos? "Si Jesús quería mostrar su poder divino, debiera haberse mostrado a los que lo insultaron, al juez que lo condenó y a todo el mundo en absoluto" (II,63, cf. II,67). Para Celso, una verdadera prueba para la fe habría sido aparecerse resucitado a los fariseos, a Pilato y a todos. Porfirio, más tarde, agregará "al Senado romano" (cf. Contra los cristianos, fr. 64).

Por otra parte, Celso insiste que la resurrección de Jesús no tiene ninguna diferencia con la de Asclepio, Dionisio, Heracles y otros (cf. III,42; II,55), e incluso 
la de Asclepio es superior: "Una gran multitud de hombres, griegos y bárbaros, confiesan que han visto [a Asclepio] muchas veces y aún ahora lo ven, no como un fantasma, sino a él mismo sanando, haciendo beneficios y prediciendo el futuro" (III,24).

En síntesis, a los ojos de Celso el argumento de la resurrección es débil, puesto que en nada se diferencia de los prodigios proclamados por muchos a quienes no se da crédito, e incluso es inferior; los relatos de las apariciones afirman que Jesús se apareció como una sombra; y, finalmente, los testigos de la supuesta resurrección son pocos, e indignos de fe.

\section{e) El argumento del martirio}

Algunas fuentes del siglo II muestran que los autores cristianos utilizaban el martirio como argumento para probar la verdad del cristianismo (A Diogneto, VII,79). Tanto Justino como Tertuliano atribuyen su propia conversión al espectáculo de los mártires (10). Hipólito escribe: "A la vista de estos prodigios todos quedan estupefactos... y en gran número son atraídos a la fe por el ejemplo de los mártires" (Com. Daniel II,38). Un fragmento del Discurso verídico sugiere que Celso conoció este uso apologético del martirio (cf. I,8).

Ante esta prueba, Celso reacciona intentando mostrar -con razonamientos menos sólidos- la inconsecuencia del martirio. Recuerda que los discípulos, que conocieron a Jesús de cerca, ante la pasión, no despreciaron los tormentos, sino que huyeron, y pregunta: ¿Ustedes se van a dejar matar? (cf. II,45). Afirma que son los mismos cristianos quienes azuzan a la autoridad romana para que los lleve a los tormentos (VIII,65) y declara absurdo esperar una resurrección corporal y a la vez despreciar los tormentos del cuerpo (VIII,49).

En conclusión, Celso rebate cada uno de los argumentos apologéticos utilizados por los cristianos: las profecías se podrían aplicar a cualquiera; los milagros muestran que Jesús en nada se distingue de los hechiceros; no hay ningún testigo fidedigno de la resurrección; y el martirio es un absurdo. Por lo tanto, concluye Celso: Jesús "fue un hombre, y así lo manifiesta la verdad y lo prueba la razón"

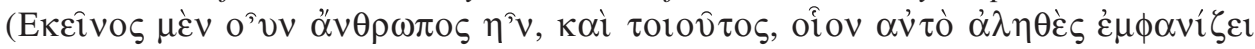

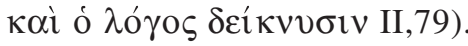

\section{Los cristianos exigen una fe inmediata y sin argumentación}

El Discurso verídico acusa a los cristianos de rechazar la sabiduría y optar por una fe sin apoyo racional. Celso transmite varias sentencias que, según él, repiten

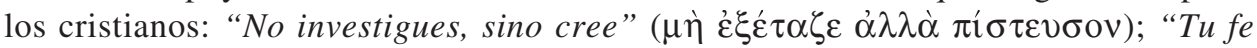
te ha salvado"; "Mala cosa es la sabiduría de este mundo; pero buena es la necedad” (cf. I,9); “ique nadie se dedique a la ciencia!” (III,75); "Cree si quieres

(10) Cf. Justino, Apología II,12; Tertuliano, Apologético 50; W. Rordorf, Martirio en DPAC, II pp. 1376-1377. 
salvarte, o márchate" (VI,11). Tras estas afirmaciones se aprecia una mala comprensión de algunos textos bíblicos, como las palabras de Pablo: "la sabiduría de este mundo es necedad" (1Cor 3,19), y las de Jesús: “tu fe te ha salvado” (Mt 9,22). Posiblemente, esta mala interpretación se debe tanto a la mala voluntad de Celso, como a la mala comprensión de los predicadores cristianos.

Los cristianos, según Celso, exigen a sus seguidores "creer inmediatamente"

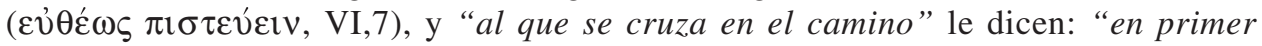
lugar, cree que este, de quien te hablo, es el Hijo de Dios" (VI,10). Contrapone a esta actitud fideísta, la de Platón, que se vale de preguntas y respuestas, es decir, de argumentación (cf. VI,7-10). Pero como los creyentes no son capaces de sustentar racionalmente su discurso, insisten: "No investigues, sino cree" (I,9), y "la fe les domina la mente” (III,38-39). Ante esto, Celso objeta:

"Si unos -refiriéndose a los cristianos-proclaman a uno y otros a otros, y todos tienen a la mano como un santo y seña: "Cree si quieres salvarte, o

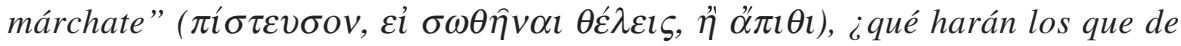
veras quieren salvarse? ¿Tendrán que tirar los dados al aire para adivinar adónde hayan de volverse y a quién adherirse? (VI,11).

La objeción es aguda, y al parecer, los cristianos conocidos por Celso abusaban de esta discurso fideísta. La invitación a creer o marcharse es frágil, y deja perplejo a los que, con sinceridad, buscan la verdad, pero se ven solicitados por diversos grupos que les proponen la misma disyuntiva: "Cree si quieres salvarte, o márchate".

Incluso algunos invitan a creer en la filiación divina de Jesús precisamente por el carácter deshonroso de su muerte, afirmando: "Por esto cree aún más" (VI,10). En consecuencia, ironiza Celso, otro que sea condenado en términos más miserables debe ser tenido como enviado de un Dios mayor (cf. II,44; II,47).

En estas circunstancias, según Celso, a los cristianos solo les queda buscar a la gente más vulgar. Son muy abundantes las acusaciones en este sentido. El elitismo y clasismo pagano se hacen evidentes:

"Vemos, efectivamente, en las casas privadas a cardadores, zapateros y bataneros, a la gente, en fin, más inculta y rústica, que delante de los señores de casa, hombres provectos y discretos, no se atreven a abrir la boca; pero apenas toman aparte a los niños, y con ellos a ciertas mujercillas sin seso, ¡hay que ver la de cosas maravillosas que sueltan!” (III,55).

Llaman solo a gente tonta y de condición servil (III,18, cf. I,27; III,50; VI,1213). "El maestro cristiano anda en búsqueda de necios" (III,74). Y no solo de necios, sino también de pecadores. Mientras todos los maestros buscan a los buenos, según Celso, los cristianos pregonan:

"Cualquiera que sea pecador, cualquier insensato, cualquier niño pequeño $y$, en una palabra, cualquier miserable, a este lo aceptará el reino de Dios” (III, 59). 
Los cristianos afirman: "Dios fue enviado a los pecadores" (cf. III,62; Mt 9,11-13). Y ante esto Celso reacciona: "Pues qué, ¿no fue enviado a los sin pecado? ¿Qué mal es no haber pecado?” (III,62; cf. III,49; III,64); y “QQué mal hay en ser instruido y prudente?” (III,49). Los llamados son: “los tontos, plebeyos, estúpidos, mujerzuelas y chiquillos" (III,49). El motivo de esta actitud cristiana es clara para Celso:

"Entre los cristianos se dan órdenes como esta: Nadie que sea instruido se nos acerque [...] No, si alguno es ignorante, insensato, inculto o tonto, venga con toda confianza. Ahora bien, al confesar que tienen por dignos de su Dios a gente de este tipo, bien claramente manifiestan que no quieren ni pueden persuadir más que a necios, plebeyos, estúpidos, esclavos, mujerzuelas y chiquillos” (III,44).

Según Celso, los cristianos no son capaces de convencer a los sabios, y por eso huyen de ellos; y, por el contrario, son muy hábiles para persuadir a los necios, y por eso los buscan (cf. III,50; III,65; VI,12; VI,14). La doctrina cristiana es insostenible, por eso piden fe inmediata, evitan a los sabios y buscan a los tontos. Ante esta actitud, Celso exhorta a los cristianos a "seguir la razón y una guía racional ( $\lambda o ́ \gamma \omega$

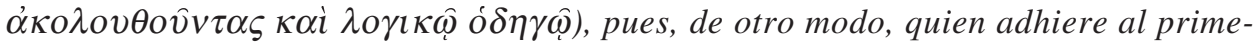
ro que topa, ha de caer de todos modos en el engaño" (I,9).

Hay que recordar que estas acusaciones se ajustan a los cristianos que ataca Celso, pero que simultáneamente, había otras corrientes cristianas más cultas, representada por los apologistas, y posteriormente por la escuela de Alejandría, que asumen el desafío de presentar la fe a buen nivel racional. El propio Orígenes no niega la existencia de este tipo de discurso entre los cristianos, pero dice que se trata de mиy pocos, que se creen cristianos, pero que están al margen de la enseñanza de Jesús, no se trata de los más instruidos, sino de los más ignorantes (cf. III,44). Pero hay que recordar que Orígenes nos transmite la situación eclesial de unos 70 años después de la redacción del Discurso verídico.

\section{HAY MOTIVOS PARA NO CREER EN EL CRISTIANISMO}

Celso no solo reacciona contra los argumentos de la primitiva apologética cristiana, para mostrar que no hay motivos para creer en Jesús, el Discurso verídico va más allá, e insiste en que hay motivos para no creer. Los blancos del ataque serán la contradicción de la Escritura, la indignidad de la historia de Jesús, la inatendibilidad de los testigos del cristianismo, la impotencia del Dios cristiano y la irracionalidad de la doctrina.

\section{Ataques al origen del cristianismo y de su doctrina}

Celso es un romano tradicionalista, que ve en el cristianismo una amenaza para la cultura clásica. Para él, lo más antiguo es lo mejor (cf. I,14; I,16; I,20; VI,80; VIII,53). En este contexto, acusa al cristianismo de abandonar lo tradicional y esta- 
blecido: Los cristianos son judíos que han renunciado a las leyes paternas (cf. II,1; II,4; V,33), y, a su vez, los judíos son prófugos de Egipto (cf. III,6; III,8; IV,31). Lo propio de ambos grupos es la sedición:

"Los judios son egipcios de raza, que abandonaron Egipto por rebeldía contra la comunidad egipcia y por desprecio de la religión tradicional en Egipto. Lo que ellos hicieron a los egipcios, lo han sufrido de parte de los que se han adherido a Jesús y han creído en Él como Mesías; y en unos y otros, la causa de la novedad fue la rebeldía contra lo comúnmente establecido” (III,5).

En síntesis, para Celso, los cristianos son judíos apóstatas y los judíos son egipcios apóstatas. La sedición está al origen de los judíos y cristianos (cf. III,7; VIII,2), en circunstancias que "es impío transgredir lo que desde el principio está establecido en cada lugar” (V,25, cf. V,34;). Según Celso, es tal el afán de subversión entre los cristianos, que están entre ellos muy divididos, y "si todos los hombres quisieran ser cristianos, ellos ya no lo querrían” (III,9; cf. III,10-14; V,61-64).

En cuanto a la doctrina cristiana, Celso considera que en ella no hay novedad, porque no es más que la corrupción de las enseñanzas de los griegos (cf. I,04; I,24; IV,11; IV,21; IV,36; VII,28; VII,32; VII,45; VII,58; VII,62). Orígenes expone esta estrategia: "Celso, en efecto, presenta muchos pasajes, en especial de Platón, equiparándolos a algunos textos de las Sagradas Escritura, capaces de impresionar incluso a uno inteligente, y dice: 'todo esto ha sido dicho mejor entre los griegos, sin hacer intervenir amenazas o promesas de un Dios o Hijo de Dios' (VI,1). Luego, según el autor pagano, todo lo que vale la pena de la enseñanza bíblica, ya había sido dicho por los griegos; lo único propio del evangelio es la rudeza del estilo: "Tienen también un precepto de no vengarse de quien los agravia. Si te pegan, dice, en una mejilla, tú presenta también la otra (Lc 6,29). Esto también es muy antiguo y anteriormente fue muy bien dicho, pero que [los cristianos] lo han repetido de modo mucho más vulgar" (VII,58; cf. Critón 49bc; V,65; VI,16). Por otra parte, alega que toda la doctrina cristiana ha sido tomada de la Ley (cf. II,5-6;). Por lo anterior, según Celso, nada hay de venerable ni de novedoso en la enseñanza de los cristianos.

\section{La Escritura es contradictoria}

Refiriéndose a la Escritura, Celso afirma que los cristianos: "se contradicen a

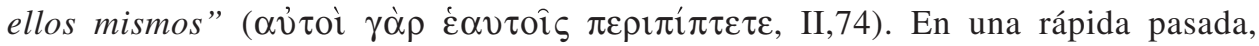
ridiculiza varios episodios bíblicos, centrándose en el relato de la creación:

"Los judios [...] compusieron la leyenda más absurda y sin gracia de cierto hombre plasmado por las manos de Dios e insuflado; de una mujer sacada del costado [del hombre]; de unos mandatos de Dios; y de una serpiente que se habría opuesto a ellos, y de la serpiente que habría podido más que los mandatos de Dios. Un mito de viejas, en que presentan, con la mayor impiedad, a Dios ya desde el principio como un impotente, incapaz de convencer ni a un hombre solo, al que acababa de plasmar" (IV,36). 
Ciertamente, una lectura estrictamente literal de la Escritura entrega abundante material para la sátira. Según Celso, como Moisés no sabía nada de la naturaleza del mundo, solo compuso tonteras (cf. VI,49-50), pues, es muy necio que la creación se distribuya en seis días: “¿qué días podía haber cuando no se había creado aún el cielo, ni estaba asentada la tierra, ni el sol giraba en torno a ella?" (VI,60), y que después de los seis días Dios quedara cansado y necesitara descansar (cf. VI,61). Todo esto lo considera simplemente absurdo ( $\ddot{\tau} \tau \pi \varsigma)$.

Asimismo, ridiculiza el Arca de Noé, que considera un cuento para niños pequeños (cf. IV,41). Recuerda a las hijas de Lot, las uniones de los patriarcas con sus esclavas, las rivalidades entre los hermanos y la historia de José, todo esto, destacando lo más insostenible de los relatos (cf. IV,43-47).

Celso critica fuertemente también el carácter antropomórfico del Dios del Antiguo Testamento. Reacciona contra esta imagen impía de un Dios que "se irrita, enfurece y amenaza", que "hace y padece cosas torpísimas", y que "come carne de oveja” (cf. IV,73; IV,72; VIII,13), e insiste en que "Dios no tiene cuerpo ni voz” y, por lo tanto, no pudo hacer al hombre a imagen suya (cf. VI,62-64; VII,27).

La crítica de Celso también se dirige al Nuevo Testamento. Considera contradictorio que a Jesús se le presente como hijo de reyes, en circunstancias que era hijo de la mujer de un carpintero (cf. II,32); le parece imposible que Jesús haya sabido que lo iban a traicionar, y por lo tanto las predicciones que aparecen en los evangelios son falsas; el hecho que los evangelios sean cuatro, es porque sucesivamente han sido modificados para responder a la objeciones, y hasta entre ellos hay contradicciones (cf. II,27). En síntesis, Celso dice a los cristianos: "Ni mintiendo fuisteis capaces de encubrir verosímilmente vuestras invenciones” (II,26).

En defensa de la Escritura, ya en el siglo II, había cristianos que la interpretaban alegóricamente, resolviendo así sus dificultades. Celso conoce este procedimiento, pero declara:

"Los más moderados entre judíos y cristianos tratan de explicar todo esto alegóricamente, avergonzados de tales historias, buscando refugio en la alegoría [...] Pero hay cosas que no admiten alegoría, sino que son cuentos simplemente tontísimos" (IV,48.50; cf. I,27; IV,51).

De este modo, a los ojos de Celso, la Escritura misma de los cristianos es un motivo para no creer en Cristo, porque su contenido es insostenible, sus relatos impíos y contradictorios, y la alegoría no puede ser utilizada, pues se trata de cuentos tontísimos.

\section{Ataques contra la historia de Jesús}

Otro blanco de Celso es la historia misma de Jesús. En primer lugar, le parece absurdo que Dios tenga que "bajar" a la tierra: ¿Qué sentido podría tener -se pregunta Celso- una bajada de Dios a la tierra?, ¿para enterarse de lo que pasaba?, ¿no era posible arreglar las cosas desde arriba, con poder divino, sin mandar a alguien?, o ¿querría darse a conocer?, y cuando baja ¿abandona su propio trono?, ¿tendrá que sufrir un cambio? (cf. IV,3; IV,5-6; IV,14; IV,18; V,2). Asimismo, la 
encarnación también le parece inaceptable: ¿Dios con un cuerpo humano común? El cuerpo de Dios debía ser diferente al de los hombres, ¿cómo podría Dios tener un cuerpo mortal? (cf. I,69-70; III,41). Esta misma aversión al cuerpo se expresa en su opinión sobre la resurrección corporal (11).

Además, Celso transmite algunas calumnias judías contra el nacimiento de Jesús (cf. I,28; I,32; I,39; II,13), y critica la impotencia de Jesús ante sus perseguidores: Si era Dios e Hijo de Dios, ¿por qué vivió escondiéndose?; ¿por qué huyó a Egipto? (cf. I,61; I,66). "Si era Dios, no tenía por qué huir ni consentir ser conducido atado y, menos que nada, ser abandonado y traicionado por los que convivían con él" (II,9, cf. II,12).

Naturalmente, a Celso le choca que los cristianos afirmen que padeció aquel mismo a quien declaran Dios (cf. II,16). Le parece que la pasión atenta contra la doctrina común de la inmutabilidad divina (cf. IV,14; II,23; VI,42; VI,74) (12); y se pregunta ¿por qué no evitó la traición y el sufrimiento? (cf. II,17; II,18-19), si era Dios, no podía sufrir verdaderamente ni menos morir (cf. II,23). Y tal como se ha dicho, Celso critica la fragilidad de las apariciones de Jesús resucitado (cf. II,70; II,72-73).

Luego, Celso se pregunta: “Qué hizo Jesús de noble o insigne como Dios?” (II,33). Nada lo demuestra como divino, y -según Celso- "es imposible que quien tiene algo divino, superior a los demás, no se distinga en nada de nadie” (VI,75).

\section{El Dios de los cristianos es impotente}

Otro motivo que destaca Celso en su ofensiva contra la verdad del cristianismo es la impotencia del Dios que proclaman. Ya en el relato del pecado original, Dios se manifiesta como impotente para convencer a un solo hombre, ;al que acababa de plasmar! (cf. IV,36). El mismo Hijo de Dios vivió escondiéndose, como incapaz de defenderse de sus enemigos (cf. I,61; I,66; II,9). En cuanto a la eficacia del ministerio de Jesús, Celso se pregunta: Si vivo no convenció a casi nadie, ¿a quién convencerá estando ya muerto? (cf. II,46; cf. II,39). Durante la Pasión, su Padre no lo ayudó (puesto que Celso no da crédito a la resurrección, cf. I,54; II,55).

Otra prueba con la que Celso afirma la falsedad del Dios cristiano es su ineficacia al no castigar a sus enemigos (13). Según el Discurso verídico, algunos cristianos, para probar la vacuidad de los dioses paganos, afirmaban: "Yo me acerco a la estatua de Zeus, de Apolo o de cualquier otro dios, blasfemo de ellos y les doy puñetazos, y no se vengan en absoluto" (VIII,38). A estos cristianos, Celso les responde:

(11) La resurrección de la carne le parece a Celso una esperanza digna de gusanos que están apegados al cuerpo (cf. V,14; VII,33-34; VI,36).

(12) Cf. H. Frohnhofen, APATHEIA TOU THEOU. Über die Affektlosigkeit Gottes in der griechischen Antike und bei den griechischsprachigen Kirchenvätern bis zu Gregorios Thaumaturgos, Frankfurt am Main, 1987.

(13) Se trata de un tema de la teodicea clásica, tal como aparece en el De sera numinis vindicta de Plutarco, en que se enfrentan las tesis estoica y epicurea acerca de la providencia. La demostración de la ausencia de providencia en el mundo, por parte del epicureo, es que los malos no son castigados. 
"Tú, insultando las estatuas de los dioses, te ríes (quizá no te irías tan alegre después de haber insultado a Dionisio o a Heracles en persona). En cambio, los que tendieron en la cruz y atormentaron a tu Dios en persona, ni ellos, los autores del atropello, sufrieron nada, ni después de tan largo espacio ha pasado nada. ¿Qué novedad ha ocurrido desde entonces por la que pudiéramos creer que aquel no fue hechicero, sino el Hijo de Dios? [...] Pero acaso dirás que aquel lo quiso así, y por ello se dejó maltratar. Pues también yo pudiera contestarte que estos, a quienes tú blasfemas, también lo quieren así, y por eso aguantan que tú blasfemes" (VIII,41).

La falsedad del Dios cristiano se demuestra -según Celso- por su ineficacia: hasta ahora no ha castigado a los que mataron a su Hijo y persiguen a sus seguidores (cf. VIII,39). Más aún, la suerte de judíos y cristianos demuestra, según él, la impotencia del Dios de la Biblia que prometió grandes cosas al que lo adorara: "y ya veis de qué les aprovechó a ellos y a vosotros. Y es así que a los judíos, en vez de hacerlos señores de toda la tierra, no les ha dejado ni un terrón ni un hogar en ella; y en cuanto a vosotros [cristianos], si es que aún queda alguno que ande por ahí errante, se los busca para darle muerte” (VIII,69). La inoperancia del Dios bíblico se prueba por el hecho que los judíos no tienen patria y que los cristianos están cerca de extinguirse por la persecución.

\section{Los testigos del cristianismo son inatendibles}

En cuanto a los testigos de los acontecimientos y la doctrina transmitidos por los cristianos, Celso es severo. Se pregunta: ¿Quién vio todo esto? (I,41). Considera tan vulgares a los testigos que le parece que ellos son, por el contrario, un motivo para no creer:

"Ningún hombre prudente creerá en esa doctrina [cristiano], retraído por la muchedumbre misma de los que la abrazan" (III,73).

Según Celso, los cristianos mismos son un buen motivo para no creer en el cristianismo. Ya ha sido tratado el tema de los testigos de la resurrección, en que el filósofo pagano pregunta: “¿Y quién vio todo esto?”, a lo que responde: “Una mujer exaltada y algún otro del mismo grupo de hechiceros" (II,55). Además, destaca el origen vulgar de los discípulos de Jesús (cf. I,62). Ciertamente que este tipo de testigos no son dignos de fe y, más aún, la ausencia de testigos más calificados parece ser un motivo para no creer.

\section{Crítica a la pretensión universal de una revelación histórica}

Una importante objeción, tal vez menos brillante desde el punto de vista de la eficacia retórica, pero de gran profundidad intelectual, es la que impugna el valor universal a una revelación concreta e histórica. Celso no la formula de modo explícito, pero está a la base de muchas de sus afirmaciones. Un párrafo muy irónico contiene lo fundamental de esta objeción. Celso compara a los cristianos a: 
"un grupo de murciélagos, o a hormigas que salen de su nido, o a ranas que celebran sus sesiones al borde de una charca, o a gusanos que allá en un

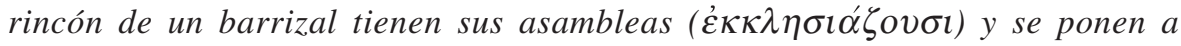
discutir quiénes de ellos son los más pecadores y discursean así: 'A nosotros Dios nos revela y anuncia todo de antemano, y, abandonando todo el cosmos y el curso del cielo, y despreciando la tierra inmensa, con nosotros solos ( $\eta \mu \hat{\imath} v$

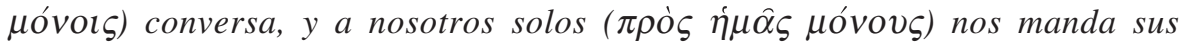
mensajeros, y nunca deja de mandarlos y buscar modos para que gocemos eternamente de su convivencia", $(I V, 23)$.

A pesar de la forma ofensiva, hay que reconocer que, entre insultos, se propone una objeción de gran peso intelectual. A Celso le parece inconcebible que un grupo tan miserable como los cristianos se considere a sí mismo como el único destinatario de la providencia y de la revelación divina, y en consecuencia, los maestros cristianos digan: "escúchennos solo a nosotros" (cf. III,75). Que Dios se les revele, podría ser aceptado, pero que se les revele a ellos solos, es absolutamente inaceptable. A continuación del fragmento anterior, compara a los cristianos con gusanos que dicen:

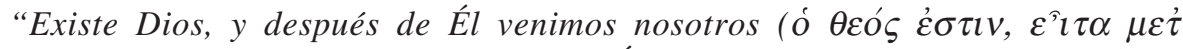

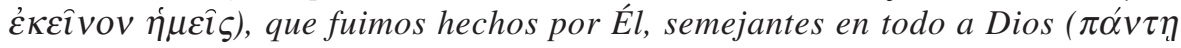
ö $\mu$ oror $\tau \hat{\omega} \theta \varepsilon \omega)$. Todo nos está sometido: la tierra, el agua, el aire, las estre-

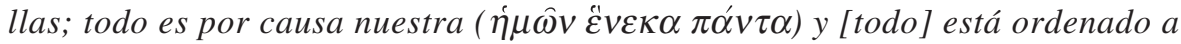

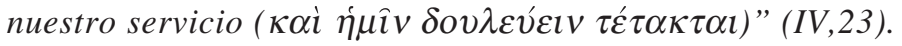

A Celso le molesta este "cristianocentrismo" de los creyentes. En términos generales, le parece inaceptable que un grupo piense que todo gira en torno a ellos. El filósofo pagano incluso rechaza el antropocentrismo: Las cosas suceden en función del bien del todo, y no en función del hombre (cf. IV,69); Dios se preocupa de los hombres tanto como de las moscas y de las hormigas (cf. IV,75-77), e incluso se pregunta: ¿No habremos sido hechos nosotros en función de los animales? (cf. IV,78-88). Finalmente declara: El universo no fue hecho para el hombre ni para los animales, sino para el bien del todo (cf. IV,99; VIII, 21).

Si Celso no acepta que Dios haya hecho todo para el hombre (IV,74), con mucha mayor razón le parece ridículo que los cristianos, un grupo de gente vulgar, originado en la oscura Palestina, periferia del Imperio, se atreva a decir: "Existe Dios, y después de Él venimos nosotros" o que "todo es por causa nuestra”. Celso rechaza la pretensión de exclusivismo tanto por parte de los judíos como de los cristianos. Considera a los judíos un pueblo ignorante, acorralado en un rincón de Palestina (cf. IV,36), y habla irónicamente de "la Gran Iglesia", un grupo que él considera despreciable (cf. V, 59), precisamente para ridiculizar su pretendida relación exclusiva y particular con Dios: "con nosotros solos conversa, y a nosotros solos manda sus mensajeros" (VI, 78). El exclusivismo cristiano es lo que molesta a Celso: el Dios absoluto y universal, debe ocuparse del todo, y no de un pequeño grupo de miserables.

En otro fragmento, Celso compara al Dios de los cristianos con el Zeus de la comedia cómica que se despierta, después de un largo sueño, con el fin de 
librar a los hombres de sus males, lo que nos presenta nuevos aspectos de la misma objeción:

“Además, si Dios, despertando de un largo sueño, como el Zeus de la comedia, quería librar al género humano de sus calamidades, ¿por qué mandó en ese

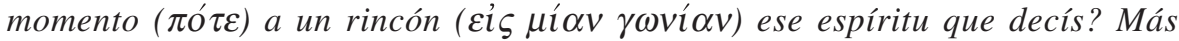
bien debiera haber soplado igualmente en muchos cuerpos y haberlos enviado por toda la tierra" (VI,78).

El fragmento presenta varias objeciones al carácter concreto de la revelación: ¿por qué en un momento específico?; ¿por qué en un único rincón de la tierra?; ¿por qué por medio de un único mensajero?

A los ojos de Celso, representante de la cultura imperial del siglo II, eminentemente tradicionalista, la antigüedad era un argumento para probar la bondad de las cosas (14). En ese contexto, los cristianos proclamaban una novedad que había ocurrido hacía menos de 140 años (15). La objeción se podría esquematizar así: Si la intervención divina, que afirman los cristianos, beneficia a los hombres, entonces, ¿por qué Dios se tardó tanto en actuar? ¿Qué sucede con los grandes de la cultura clásica, que nacieron antes de la inauguración de la Verdad?

¿Acaso [solo] ahora -objeta Celso-, después de [todos] estos siglos, Dios se acordó de juzgar la vida de los hombres que, anteriormente, por el contrario, desatendia? $(I V, 7)$.

Se trata de la pregunta: Cur tam sero revelatus est? En otros fragmentos insiste en que Jesús apareció recientemente, "ayer o anteayer" (II,4; cf. I,26; VI,10; VIII,12). Celso considera que si Dios quería revelarse, debió enviar su espíritu en

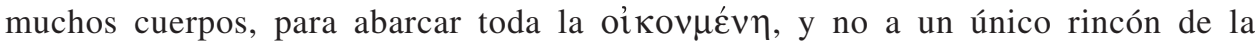
tierra. Le molesta, por tanto, el carácter exclusivista de la predicación de los cristianos. A veces Celso está dispuesto incluso a aceptar que Jesús sea un ángel, pero,

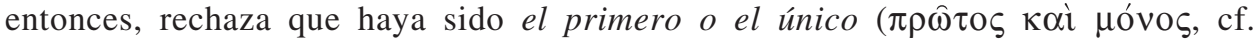
$\mathrm{V}, 52$ ), en circunstancias que, de acuerdo al Discurso verídico, los cristianos exhor-

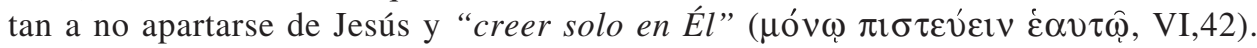
Para Celso, Jesús no es Hijo de Dios, pues Dios es padre de todos ( $\pi \imath \sigma \tau \varepsilon v ́ \varepsilon \imath v$ $\pi \alpha \tau \eta ́ \rho)$ y solo a Él hay que adorar; (VIII,14), y no acepta el carácter exclusivo ni de Jesús ni de su mensaje (cf. VIII,11; VIII,15).

Y para coronar la presunción exclusivista de los cristianos, los predicadores amenazan con castigos eternos a todos los que no adhieran a su doctrina (cf. IV,10;

(14) Así, por ejemplo el pagano Cecilio en Minucio Félix, Octavius, 6,3: "En efecto, la antigüedad suele otorgar tanta santidad a las ceremonias y a los templos, cuanto se prolongue por la perduración en el tiempo" (Quippe antiquitas caeremoniis atque fanis tantum sanctitatis tribuere consuevit, quantum adstruxerit vetustatis).

(15) Esta dificultad es enfrentada por el autor de la Carta a Diogneto: ¿Por qué el cristianismo apareció precisamente ahora y no antes? (cf. Ep. ad Diogn., I). También por Justino, Apología I,46: “Algunos, sin razón, para rechazar nuestra enseñanza, pudieran objetamos que, al decir nosotros que Cristo nació hace solo ciento cincuenta años bajo Quirino y enseñó su doctrina más tarde, en tiempo de Poncio Pilato, ninguna responsabilidad tienen los hombres que le precedieron. Adelantémonos a resolver esta dificultad". 
VIII,48; además VII,9). Según el autor pagano, tanto judíos como cristianos creen que "cuando Dios traiga el fuego, todo el género humano quedará quemado y solo ellos sobrevivirán” (V,14). Así, a los ojos de Celso, estos, que se proclaman los únicos destinatarios de la revelación, presumen ser también los únicos salvados.

\section{CONCLUSIÓN: NÚCLEO DE LA CRÍTICA DE CELSO Y DESAFÍOS AL CRISTIANISMO}

Ante estos múltiples ataques, de desigual violencia y profundidad, es necesario preguntarse cuál es el núcleo de la crítica y cuáles los retos que surgen de ella (16). Estas críticas no son meros insultos, y tienen un sustrato atendible, que se vuelven desafíos a la naciente fe cristiana.

1. La sátira de Celso respecto de las Escrituras es un estímulo para reflexionar en torno de la necesidad de interpretar el texto sagrado. Algunas expresiones bíblicas, contradicciones en el texto, los antropomorfismos, la moralidad de los patriarcas, la discordancia de los relatos evangélicos entre sí, etc., son signos claros de que es inadmisible una lectura rígidamente literalista el texto sagrado, y que, por tanto, es necesario enfrentar el desafío de la interpretación. En todo caso, no es mérito de Celso el planteamiento de esta tarea, puesto que ya el judaísmo helenista, y el cristianismo católico, frente a la cultura griega, a las escuelas gnósticas y a Marción, ya se lo había planteado este desafío.

2. De la lectura de la obra de Celso, resulta evidente la insuficiencia del discurso fideísta de algunos predicadores cristianos, y se plantea la necesidad de reflexionar la fe. La lógica del "cree si quieres salvarte, o márchate”, es insostenible, y la objeción que le hace Celso es verdaderamente contundente: frente a tantas propuestas fideístas, ¿cómo discernir cuál es el camino verdadero?

Es interesante constatar que el autor pagano no percibe el discurso fideísta como una exigencia del mensaje evangélico, sino, más bien, lo considera un refugio ante la incapacidad de argumentar de los cristianos. Nuevamente, vale la pena recordar que esta objeción se ajusta bien a los cristianos que describe Celso, en circunstancias que las fuentes antiguas nos testifican la existencia de otras corrientes cristianas que buscaban a tientas el modo de expresar el mensaje evangélico a buen nivel intelectual (17). Y así, en este caso, la polémica no expresa un verdadero punto de conflicto entre la fe y la razón, sino entre un cristianismo no reflexionado y la razón.

3. Al considerar las diversas críticas paganas en su conjunto, se percibe una raíz común. En el Discurso verídico Celso expresa: a) su radical oposición a la novedad del cristianismo (que considera una corrupción vulgar del judaísmo y del helenismo); b) su aversión a la "bajada” del Dios supremo y a la encarnación, es decir, a la real presencia del Dios universal en un cuerpo como el nuestro; c) su

(16) Vale la pena recordar que la cultura romana era muy tolerante y abierta a recibir influjos extranjeros, lo que hace más relevante la pregunta acerca de por qué se desata esta crítica tan violenta, por parte de este intelectual romano.

(17) Tal como lo había hecho Filón en el judaísmo helenístico del siglo I, en Alejandría. 
persistente negación de cualquier acción divina que beneficie a un grupo particular (negando así cualquier teología de la elección); y, sobre todo, d) su rechazo de la pretensión de universalidad de una revelación que se realiza en un momento puntual, en un lugar determinado y por medio de un individuo particular. Todas estas objeciones tienen como raíz común el rechazo de Celso a aceptar que el Dios universal y absoluto se manifieste de modo concreto en la historia, es decir, en la limitación del tiempo y del espacio. Aquí sí nos encontramos con un verdadero punto de conflicto entre el paganismo y el cristianismo.

Para comprender el problema hay que tener en cuenta la concepción del tiempo y de Dios propias de Celso. El autor del Discurso verídico tiene una visión cíclica

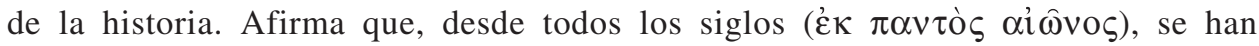

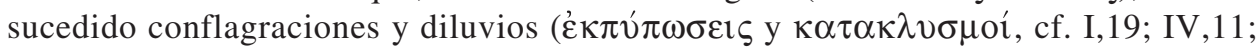
IV,79; Timeo, 22a-b; Critas, 122a). El mundo es cíclicamente destruido y regenerado. Esta concepción, de origen estoico (18), tiene como consecuencia el eterno retorno de la historia:

El itinerario circular de los mortales -afirma Celso- es igual desde el principio hasta el fin, pero, de acuerdo a los ciclos ordenados, es necesario que sea siempre lo mismo aquello que fue, que es y que será $(I V, 65)$.

Lo que fue, lo que es y lo que será, es siempre lo mismo (cf. IV,65; IV,67-68; $\mathrm{V}, 20 ; \mathrm{V}, 21)$. Este carácter cíclico del tiempo, niega cualquier novedad y toda posibilidad de una real acción de Dios en la historia. Se trata de un determinismo que se realiza por medio de los procesos necesarios de la naturaleza. La providencia, para Celso, no es más que la naturaleza en marcha (19).

Esta visión de la historia tiene sus consecuencias en el ámbito de la ética. Celso declara que el mal es inherente a la materia (cf. IV,60-61). Esta visión no permite un mejoramiento ni un empeoramiento de las cosas: "los males, en lo que existe, ni antes, ni ahora, ni en otra ocasión podrían ser mayores o menores" (IV,62; cf. IV,63; IV,69). Esta visión pagana de la historia, representada por Celso, está cerrada a la verdadera novedad de la intervención divina y, por lo tanto, está cerrada a la gracia. El choque con el cristianismo aparece inevitable, puesto que la predicación de los creyentes se centra en la novedosa intervención de Dios en la historia (20).

Esta homogeneidad de la realidad se refleja también en la "teología" del autor

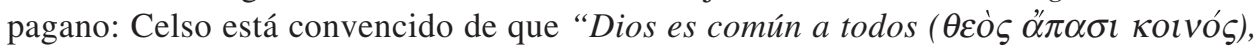
bueno, sin necesidad y ajeno a toda envidia” (VIII,21). Celso además afirma que “de

(18) Estobeo, Églogas, I,20,1e [S.V.F. I 107]: “Paréceles a Zenón, Cleantes y Crisipo que la sustancia se transforma en fuego, el cual es una especie de simiente y que, a partir de este, nuevamente se lleva a cabo la reconstrucción del mundo, tal como antes existía”.

(19) Cf. H. Chadwick, Early Christian Thought and the Classical Tradition, Oxford 1966, pp. 119-120.

(20) "The nerve-center of the debate between Origen and Celsus lies in the possibility of revelation in history: can there be grace? To Celsus the Christian doctrine means that God's freedom is arbitrary and capricious" H. Chadwick, Early Christian Thought and the Classical Tradition, p. 120. Cf. M. Fédou, Christianisme et religions païennes dans le Contre Celse d'Origène, pp. 536-537. 
Dios procede todo"; que no se puede abarcar por la razón ni nombrar, y que está fuera de todo padecimiento (cf. VI,65-66); el gobierno divino no se centra en ningún grupo particular sino solo en el bien común: "Dios se cuida del todo ( $\tau$ ò ónov) y su providencia jamás lo abandona, ni lo vuelve peor, ni se vuelve sobre el [mundo] cada cierto tiempo, ni se encoleriza a causa de los hombres" (cf. IV,99). Esta concepción de Dios ve la libertad divina como capricho y, por tanto, es rechazada cualquier teología de la elección. Dios no puede "abajarse" en un momento determinado, ni elegir un pueblo, ni preferir a los pobres y a los débiles. El Dios de Celso, entonces, es incomprensible, impasible, es el Dios común a todos, que está sobre todos y gobierna el mundo, no en favor de un grupo, ni siquiera en favor del género humano completo, sino a favor del todo ( $\tau$ ò őhov). Para este Dios universal cualquier particularismo parece ser arbitrariedad. Aquí estamos frente al verdadero punto de conflicto entre Celso y los cristianos. Hay que reconocer, por tanto, que, entre múltiples imprecisiones y formulaciones defectuosas, los predicadores cristianos del siglo II fueron capaces de expresar la genuina novedad del mensaje evangélico.

El Discurso verídico significó un desafío para los cristianos más atentos: ¿Cómo afirmar la novedad de la intervención del Dios universal en la historia concreta, sin producir una ruptura en la misma historia, y sin excluir de la providencia divina aquellos que han vivido antes de "la plenitud de los tiempos"? La novedad en la historia no puede extremarse hasta el punto de excluir parte de la humanidad de la salvación o de la providencia divinas. Se trata de un serio cuestionamiento cristológico. El carácter concreto y único de la presencia del Dios absoluto en la historia, en Jesús de Nazaret, no puede ser comprendido como si la encarnación fuera un modo más, entre otros, de la presencia divina en el mundo; pero, a la vez, la encarnación no se puede entender de modo que parte de la humanidad quede excluida del influjo salvífico del único Dios (21).

Si efectivamente y los apologistas griegos conocieron la crítica de Celso, como algunos estudiosos opinan, podríamos suponer que ella incentivó la elaboración de la fecunda doctrina de Justino acerca de las semillas del Logos (22), formulada precisamente en la misma época de la redacción del Discurso verídico. Doctrina que pretende precisamente dar razón de la eterna y constante presencia y actuación del Dios universal, y de la relevancia de la presencia concreta de Dios, en la historia, en Jesús de Nazaret.

La objeción de Celso a la pretensión de universalidad de una revelación histórica, sin duda se vio favorecida por el carácter insignificante de la comunidad que proclamaba esta revelación. En el siglo II, la Iglesia, a los ojos del pagano, era un

(21) Es el candente problema de la Redemptoris missio, planteado últimamente por la Dominus Iesus.

(22) Justino, Apología II,13,3-6. "Porque cada uno habló bien, viendo lo que con él tenía afinidad, por la parte del Verbo seminal divino que le cupo [...] cuanto de bueno está dicho en todos ellos nos pertenece a nosotros los cristianos, porque nosotros adoramos y amamos, después de Dios, el Verbo, que procede del mismo Dios ingénito e inefable; pues Él, por amor nuestro, se hizo hombre para ser partícipe de nuestros sufrimientos y curarlos. Y es que los escritores todos solo oscuramente pudieron ver la realidad gracias a la semilla del Verbo en ellos ingénita. Una cosa es, en efecto, el germen e imitación de algo que se da conforme a la capacidad, y otra aquello mismo cuya participación e imitación se da, según la gracia que de aquél también procede”. Cf. Apología II,8. 
miserable y minoritario grupo de gente sin ningún peso social. Pero esta crítica no depende solo de la baja condición social de los cristianos. Años más tarde, durante el gobierno de Teodosio, cuando la situación social de la Iglesia había cambiado radicalmente, la misma objeción seguirá presente en un tono muy distinto. El prefecto de Roma, Quinto Aurelio Símaco, que se mantuvo fiel al paganismo, aún después de Constantino, pronunció en el 384 un célebre discurso, ante Teodosio y el Senado romano, pidiendo la restitución del Altar de la Victoria, emblema de la religión del Imperio, que había sido removido por el emperador cristiano (23). Símaco, en su argumentación, ya no puede tratar a los cristianos de gusanos, ni burlarse de su baja posición social, como lo había hecho Celso; la situación había cambiado notablemente y esta vez el pagano habla desde la minoría. Pero, de modo diferente, propone la misma objeción al final de su discurso:

Es justo considerar como único a aquel a quien todos rinden culto. Contemplamos los mismos astros, el cielo nos es común, nos envuelve el mismo mundo, ¿qué interesa en qué manera uno busca la verdad? No puede ser que hasta tan grande misterio se llegue por un único camino (uno itinere non potest perveniri ad tam grande secretum). Pero estas son cuestiones de pensadores, ahora no pronunciamos un debate, sino una oración (Q. A. Symmachus, Relationes, III, 10).

Tímidamente, y de modo respetuoso, ante el emperador cristiano, Símaco en parte repite la objeción de Celso, que hasta hoy sigue siendo un desafío para la teología: ¿Cómo comprender que hasta el gran Misterio se llegue solo por un único Camino?

\section{RESUMEN}

El primer gran debate documentado entre cristianos y paganos se encuentra en el Discurso verídico del filósofo pagano del siglo II, llamado Celso. A partir de los fragmentos de esta obra, conservados en la réplica de Orígenes, se reconstruyen los argumentos utilizados por los cristianos del siglo segundo para defender su doctrina y las objeciones planteadas por Celso. Luego, siempre a partir de los fragmentos de Celso, sin atender a los insultos contra los cristianos, se sistematizan las objeciones racionales contra la credibilidad del cristianismo: Se ataca la oscuridad del origen del cristianismo, las contradicciones de la Escritura, la pobreza de la historia de Jesús, la impotencia del Dios cristiano, la inatendibilidad de los testigos del cristianismo y, sobre todo, la pretensión de universalidad de una revelación histórica. Este último punto aparece como el más relevante del ataque de Celso: Según el filósofo, el Absoluto no puede revelarse en la historia.

(23) Ante el Altar de la Victoria, dedicado en el 29 a. C., los senadores juraban fidelidad al emperador y a sus leyes. Al inicio de la era constantiniana, se planteó la incompatibilidad de ese culto pagano con la fe cristiana. En el 357 el Altar se retiró de la curia. Luego fue restituido por Juliano, y finalmente quitado por Graciano en el 382. Cf. M.G. Mara, DPAC, I, pp. 88-89. 


\begin{abstract}
The first recorded debate between Christians and Pagans is found in the veridical discourse by Celso, a pagan philosopher from the II century. This work, kept in Origens' replica, holdssome fragments of the arguments used by the II century Christians to defend their doctrine against Celso's objections. Following Celsu's fragments -and disregarding the insults against the Christians- the author systematises the rational objections against the credibility of Christianity. These are the obscurity of the origin of Christianity; the contradictions of the Scriptures; the poor quality of the history of Jesus; the impotence of the Christian God; the lack of credibility of its witnesses, and above all its claim to be a universal historical revelation. This last point seems to be Celso's sharpest attack: According to the philosopher, the Absolute can not reveal itself into history.
\end{abstract}

